\title{
Reproductive studies of Anchoa marinii Hildebrand, 1943 (Actinopterygii: Engraulidae) in the nearby-coastal area of Mar Chiquita coastal lagoon, Buenos Aires, Argentina
}

\author{
Sofía López ${ }^{1}$, Ezequiel Mabragaña ${ }^{1,2}$, Juan Martín Díaz de Astarloa ${ }^{1,2}$ and Mariano \\ González-Castro ${ }^{1,2}$
}

The aim of the present study provides the first results on the reproductive biology of the anchovy, Anchoa marinii, in a nearby-coastal area of Mar Chiquita coastal lagoon, 37 $32^{\prime} 00^{\prime}$ 'S $57^{\circ} 19^{\prime} 00^{\prime \prime} \mathrm{W}$, Argentina. To perform this, we employed mainly female gonads, at both microscopic and macroscopic levels. The oocyte diameter distribution and the microscopy analysis of oocytes, showed different batches of growing oocytes, suggesting that the anchovy is a multiple spawner, with constant oocytes recruitment all over the reproductive season. The batch fecundity ranged between 749 and 3,207 oocytes for females, and the relative fecundity ranged from 127 to 422 yolked oocytes per female gram (ovary free). The fecundity estimation has been made with yolked oocytes. No correlation between the fecundity estimation and female size and total weight (without ovary) has been found. The estimated $\mathrm{L}_{50}$ values were 74.13 and $73.76 \mathrm{~mm}$ TL for females and males, respectively. Shoals of females in advanced maturity phase were recorded, between December to April in the study area. During this period a significant increase of species abundance was correlated with water temperature increase (above $16^{\circ} \mathrm{C}$ ). This fact, together with the detection of post-ovulatory follicles, indicated the existence of reproductive events in the nearby-coastal area of Mar Chiquita coastal lagoon.

El objetivo del presente trabajo es avanzar en la comprensión del ciclo de vida de la anchoa, Anchoa marinii, en relación

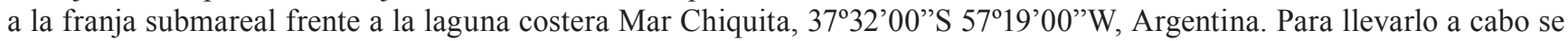
utilizaron gónadas, principalmente hembras, y se estudiaron a nivel macro y microscópico. El análisis microscópico de los ovarios evidenció la presencia de diferentes camadas de ovocitos, con un reclutamiento constante de ovocitos inmaduros durante la época reproductiva, relacionado con un patrón de puestas parciales. La fecundidad parcial arrojo valores entre 749 y 3207 ovocitos, y la fecundidad relativa estuvo comprendida entre 127 y 422 ovocitos por peso total libre de ovarios. Las estimaciones se realizaron a partir de ovarios con ovocitos vitelados. No se encontraron relaciones significativas entre las estimaciones de fecundidad y la talla o peso de las hembras. La talla de primera madurez se estimó en 74,13 mm para las hembras y 73,76 $\mathrm{mm}$ para los machos, en el área muestreada. La presencia de hembras en estadio de maduración avanzada fue muy abundante entre diciembre y abril, correlacionándose con elevada temperatura del agua (por encima de $16^{\circ} \mathrm{C}$ ). Este hecho sumado a la detección de hembras con folículos post-ovulatorios indicarían que la anchoa, Anchoa marinii, presenta actividad reproductiva durante la temporada estival, en el submareal frente a la Laguna costera Mar Chiquita.

Keywords: Clupeiformes, Fecundity, Multiple spawner, Reproductive biology.

\section{Introduction}

The Order Clupeiformes (Actinopterygii) is conformed by pelagic fish such as anchovies and sardines. This mean trophic level fish serve as food for other species (Cury et al., 2003). Clupeiform fish are components of global fisheries, contributing approximately 30 to $50 \%$ of annual catch tones (Fréon \& Misund, 1999; Bakun \& Broad, 2003). Within the
Order two families occur in Argentina: Engraulidae and Clupeidae. Five clupeiform species have been recorded in the subtidal, front of Mar Chiquita coastal lagoon: Anchoa marinii Hildebrand, 1943, Lycengraulis grossidens (Spix \& Agassiz, 1829), Ramnogaster arcuata (Jenyns, 1842), Engraulis anchoita Hubbs \& Marini, 1935 and Brevoortia aurea (Spix \& Agassiz, 1829), being A. marinii the most abundant (López, 2013).

${ }^{1}$ Laboratorio de Biotaxonomía Morfológica y Molecular de Peces (BIMOPE). Instituto de Investigaciones Marinas y Costeras, IIMyCCONICET- UNMdP. Mar del Plata, Buenos Aires. sofialopezmdp@gmail.com

${ }^{2}$ Consejo Nacional de Investigaciones Científicas y Técnicas (CONICET). ezemabra@gmail.com (EM); astarloa@mdp.edu.ar (JMDA); gocastro@mdp.edu.ar(MGC). 
The anchovy, A. marinii (Engraulidae), was described by Hildebrand (1943) based on samples from Mar del Plata and Quequén (Argentina ). It is a small demersal-pelagic species occurring in the southwest Atlantic from Cabo Frio, Brazil $\left(23^{\circ} \mathrm{S}\right)$, to Quequén coast, Argentina $\left(38^{\circ} \mathrm{S}\right)$ (Fuster de Plaza \& Boschi, 1959). Adult specimens rarely reach a maximum $145 \mathrm{~mm}$ total length, and individuals of both sexes mature at one year old (Fuster de Plaza \& Boschi, 1959). The spawning occurs, on the coast of Mar del Plata, in late spring, early summer, when the water temperature reaches high values (Ciechomski, 1968).

Despite a wide distribution range reported for $A$. marinii (which includes Brazil, Uruguay and Argentina) and its ecological importance in the food web chain of other commercially important coastal fish species such as cods, sciaenids and sharks (Cousseau \& Perrota, 2004), little information on the species has been published in the last 15 years. Eggs and larvae have been described based on samples from Mar del Plata (Ciechomski, 1968). Larvae have been observed in the Río de la Plata estuary (Uruguay) (Mantero et al., 2006), and this ontogenetic stage was correlated with waters of high salinity and temperature (when comparing with estuarine waters), correlating with the oceanic origin of the species.

Mar Chiquita coastal lagoon is located in the Buenos Aires province, $40 \mathrm{~km} \mathrm{~N}$ of the Mar del Plata city, is considered a World Biosphere Reserve by UNESCO (Iribarne, 2001). The fish composition of Mar Chiquita has been investigated during the last decade because several of the fish species occurring in the lagoon have commercial importance and or/ fish game (Díaz de Astarloa et al., 2000; Cousseau et al., 2001; Rivera Prisco et al., 2001; González Castro et al., 2006; González Castro et al., 2009; González Castro et al., 2011).

The aim of the present study is to advance in the understanding of the life history of the anchovy, A. marinii, in a coastal area nearby Mar Chiquita coastal lagoon

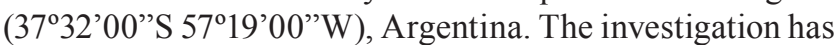
been focused on the abundance and reproductive biology, based on an annual cycle.

\section{Material and Methods}

Fish samples. Specimens were collected monthly between November 2010 and February 2013 in a coastal area of the

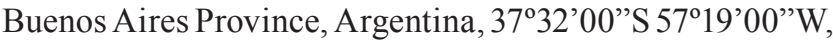
nearby Mar Chiquita coastal lagoon. Sampling composed by six trawl stations located between the surf zone and 2,500 $\mathrm{m}$ away from the coast between November 2010 and November 2012 (Fig. 1). Due to logistic troubles, in June, and October 2011, and January, February and September 2012, sampling was not carried out. The six stations were grouped together for the statistical analysis.

Fish were trawled by means of an outboard boat provided by a shrimp net with gates, net mesh size was $50 \mathrm{~mm}$ in the wings and $20 \mathrm{~mm}$ in the cod end. Each trawl station was 10 min, at an average speed of $4 \mathrm{~km} / \mathrm{h}$. Water temperature $\left({ }^{\circ} \mathrm{C}\right)$, salinity (ups), depth (m) and geographical location of each station were taken with a Horiba ${ }^{\circledR}$ multiparameter. Each fish was measured to the nearest $\mathrm{mm}$, and weighed to 0.1 g with a Metler Toledo ${ }^{\circledR}$ electronic balance. Total weight (TW) and ovary weight were recorded for each individual sampled. A macroscopic and microscopic maturity scale of five phases was employed: (1) immature, (2) developing, (3) spawning capable, (4) regressing and (5) regenerating (Brown-Peterson et al., 2011). The ovaries samples were separated and fixed in Davidson solution.

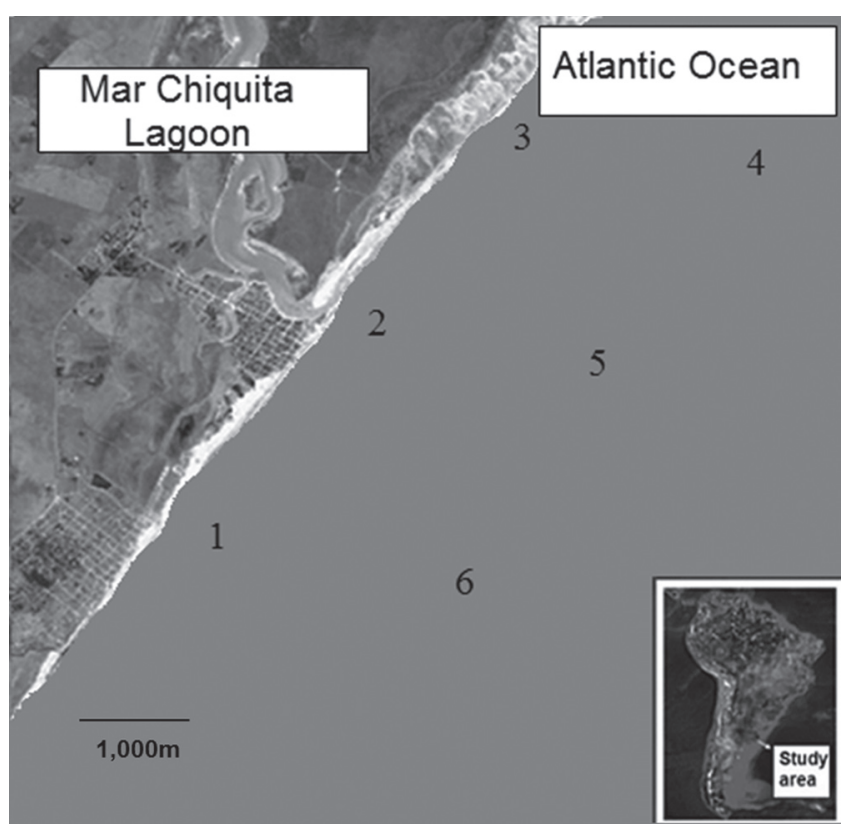

Fig. 1. Study area showing the sampling stations.

Monthly abundance estimation. The abundance of $A$. marinii between November 2010 and February 2013 was estimated by the capture per unit effort (CPUE) and plotted against salinity and water temperature with the purpose of show the monthly variations. In addition, a Pearson correlation method was made between temperature and CPUE.

Gonads analysis. At the laboratory, fixed ovaries were removed, dehydrated in ethanol, cleared in xylol and embedded in paraffin. Sections were cut at $5 \mu \mathrm{m}$ and stained with Harry's haematoxylin followed by eosin counterstain. Histological classification of ovaries was based on oocyte development stage (Brown-Peterson et al., 2011). The presence / absence of post-ovulatory follicles and atresia were also assessed.

Oocyte diameter frequency distribution. Soon after fixation, 183 ovaries in spawning capable phase were stored in ethanol $70^{\circ} \mathrm{GL}$. A total of 200 oocytes per ovary were removed, placed in water, and the longest axis was measured with an ocular micrometer. 
Fecundity estimation, Gonadosomatic index and length at first maturity $\left(\mathbf{L}_{50}\right)$. Batch fecundity (number of oocytes released per spawning) was estimated employing 20 ovaries in spawning capable maturation phase (phase 3), stored in ethanol $70^{\circ} \mathrm{GL}$ after fixation. These ovaries showed no evidence of recent spawning (no post ovulatory follicles were observed). The whole ovary was used due to, the gonad's small size. These ovaries were separated into two pieces. Later, each sample was rehydrated, weighed with analytical balance (+/- 0.0001g) and yolked oocytes were counted (greater than or equal to $0.5 \mathrm{~mm}$ ). Consequently, batch fecundity was the product of the mean of yolked oocytes per unit of ovary gram (Yo/g) and the ovary weight $(\mathrm{Ow})$.

Relative fecundity (number of yolked oocytes per gram of ovary- free body weight) was calculated as the batch fecundity divided by female weight (without ovaries). The relationship of batch fecundity to total length and to total weight; or relative fecundity to total length and to total weight were described using the Pearson correlation method (Kartas \& Quignard, 1984).

Gonadosomatic Index (GSI \%), estimated as gonad weight divided by body weight ( $\mathrm{x} 100$ ), was analysed for females in relation to the annual cycle and maturity phases.

To estimate length at first maturity, 664 females and 183 males were analysed for maturity phase determination. Later, individuals were classified as immature (Phase 1) or mature (the other phases) and grouped in $3 \mathrm{~mm}$ length classes. A logistic model was fitted to the proportion of mature individuals by total length class using the maximum likelihood method (Roa et al., 1999).

\section{Results}

Ovarian cycle and capture per unit effort (CPUE). Most of the examined ovaries were in the spawning capable phase, being mainly from October to February. Ovaries in the spawning capable or regenerating maturity phases were frequent during March and April. On May, June and July all the ovaries examined were in regenerating phase (Fig. 2). The capture per unit effort was plotted against salinity and water temperature (Fig. 3). During the time sampled, the highest CPUE values occur between December and April; high Pearson correlation coefficients $\left(r^{2}: 0,753\right)$ was detected between temperature and CPUE. Salinity showed less variability along the analyzed months, in comparison to temperature.

Stages of oocyte development. During the investigated period the following stages were observed: (A) oogonias, (B) primary growth oocyte, (C) cortical alveolus stage, (D) yolked oocytes, (E) hydrated oocytes, and (F) atretic follicle (G) post ovulatory follicles (Table 1; Fig. 4).

Gonad maturity phases. Four of the five phases of gonad maturity were found during this study:
1 Immature. Very small ovaries, pink colour with a thin tunic. At the microscopic level only oogonias (Fig. 4a) and primary growth oocytes were observed. Few specimens were found in this phase, mainly in January.

2 Developing. Characterized by increased ovarian size and blood vessels becoming more distinct. With primary growth oocytes (Fig. 4a), cortical alveoli oocyte (Fig. $4 \mathrm{~b})$ and early yolked oocytes. Few specimens were observed in this phase, during November, December and January.

3 Spawning capable. Ovaries attained one third of the abdominal cavity. They were yellow coloured and had a prominent ovaric artery. Oocytes were noticeable to naked eye, most were yolked oocytes (Fig. 4c). Specimens were observed at this phase throughout the breeding season (December-April).

5 Regenerating. Small ovaries, light pink with thick tunic. Predominantly primary growth oocytes present. This was the dominant maturity phase throughout May, June and July.

No regressing (phase four) was detected during the study period. This phase is characterized by flaccid ovaries displaying prominent blood vessel. Numerous atresias and post ovulatory follicles are present.

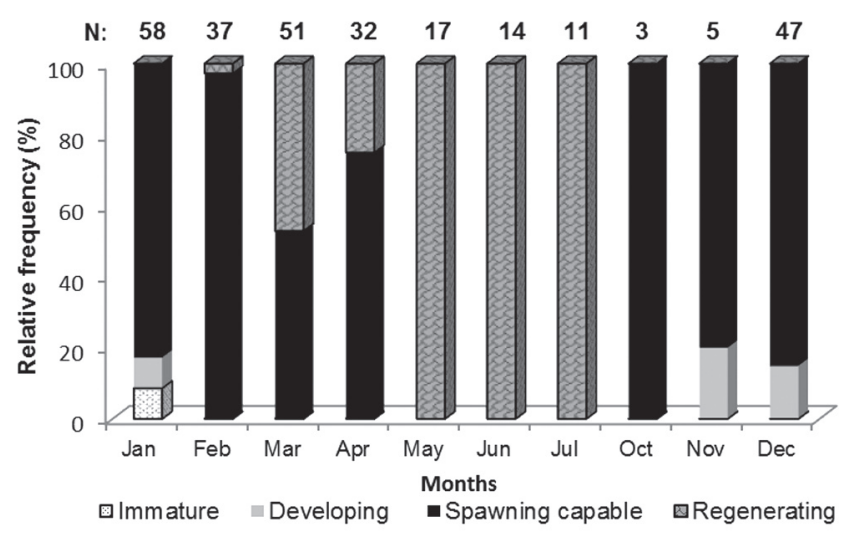

Fig. 2. Monthly relative frequency (\%) of gonad phases for females of Anchoa marinii.

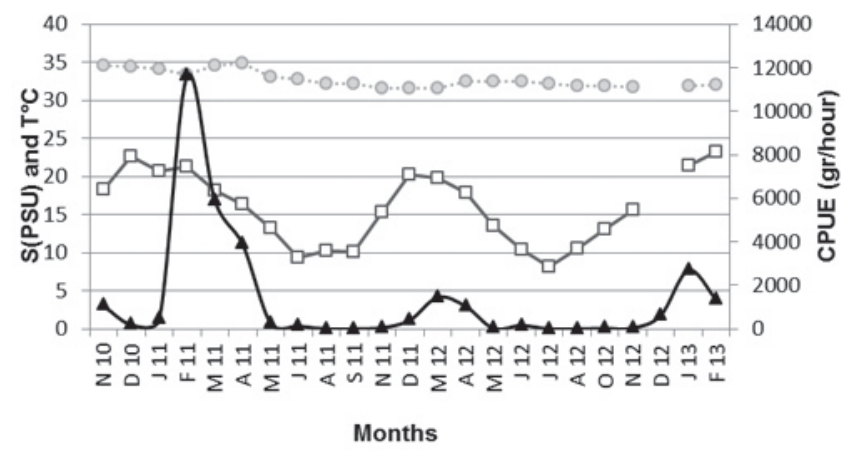

Fig. 3. Captures per unite effort (CPUE), temperature and salinity values obtained for Anchoa marinii. Black triangles: CPUE; open squares: temperature; circles with dotted line: salinity. 
Table 1. Descriptions of stages of oocyte development, atretic follicles and post-ovulatory follicles.

\begin{tabular}{|c|c|}
\hline Stages & Microscopic characteristics \\
\hline A. Oogonias & $\begin{array}{l}\text { Small cells, with } 4-7 \mu \mathrm{m} \text { diameters. Large nucleus } \\
\text { of central location rounded and with lax chromatin, } \\
\text { surrounded by scarce cytoplasm mildly basophilic. }\end{array}$ \\
\hline $\begin{array}{l}\text { B. Primary growth } \\
\text { oocytes }\end{array}$ & $\begin{array}{l}\text { Larger than oogonias (up } 200 \mu \mathrm{m} \text { ), cytoplasm } \\
\text { basophilic. Large nucleus of central location, with } \\
\text { some prominent nucleoli. }\end{array}$ \\
\hline C. Cortical alveoli & $\begin{array}{l}\text { With diameters between } 200 \text { and } 300 \mu \mathrm{m} \text {, } \\
\text { cytoplasm basophilic with small vesicles called } \\
\text { cortical alveoli. The radiata zone is visible (with } \\
\text { highly eosinophilic) and also the follicular layer } \\
\text { (granulosa and teca cells). }\end{array}$ \\
\hline D. Yolked oocytes & $\begin{array}{l}\text { Oocyte size increased diameters from } 350 \text { to } 650 \\
\mu \mathrm{m} \text {. Eosinophilic yolk protein granules present } \\
\text { throughout the cytoplasm. Radiata zone thick with } \\
\text { highly eosinophilic. The follicular cells become } \\
\text { more notorious, and the nucleus continued in } \\
\text { central position. }\end{array}$ \\
\hline $\begin{array}{l}\text { E. Hydrated } \\
\text { oocytes }\end{array}$ & $\begin{array}{l}\text { Final maturation of the oocyte started with migration } \\
\text { of the nucleus to the animal pole of the cell. After } \\
\text { this, the nuclear membrane disintegrates, dispersing } \\
\text { its contents into the cytoplasm. Subsequently, the } \\
\text { cytoplasmic hydration occurs. }\end{array}$ \\
\hline F. Atretic follicles & $\begin{array}{l}\text { Observed mainly at the end of the reproductive } \\
\text { cycle. Characterized by nucleus disintegration and } \\
\text { autolysis of yolk oocytes. }\end{array}$ \\
\hline $\begin{array}{l}\text { G. Post-ovulatory } \\
\text { follicles }\end{array}$ & $\begin{array}{l}\text { Characterized by irregular shape and advanced } \\
\text { degradation. With a small follicular lumen. }\end{array}$ \\
\hline
\end{tabular}

Frequency distribution of oocyte diameters. The size distribution of formalin-preserved oocytes (spawning capable phase) of $A$. marinii was tetramodal (Fig. 5). The smallest group was composed mainly of primary growth oocytes (smaller than $200 \mu \mathrm{m}$ ). The next larger group was composed of cortical alveolus stage ranging from 200 to $350 \mu \mathrm{m}$. A third group included partially yolked oocytes (primary yolk stage), between 350 and $500 \mu \mathrm{m}$. The fourth group included advanced yolked oocytes (secondary yolk stage) ranging from 500 to $650 \mu \mathrm{m}$. Ovaries displayed a continuous distribution from primary growth to advanced yolked oocytes as revealed by the histological analysis. This indicates a constant recruitment of pre vitellogenic oocytes to the yolked group during the reproductive season, which implies this species present an indeterminate fecundity.

Fecundity. Batch fecundity (BF) estimated ranged from 749 to 3,207 yolked oocytes for individuals between 76 to $114 \mathrm{~mm}$ TL, with a mean of 1717 yolked oocytes (Fig. 6). Unexpectedly $\mathrm{r}^{2}$ values were low, no Pearson correlation $(\mathrm{p}>0.05)$ between BF vs. TL and BF vs. TW (ovary free) were obtained from the samples.

Relative fecundity (RF) ranged from 127 to 422 yolked oocytes per female gram (ovary-free) (Fig. 6). Again, no significant relationships were obtained between RF vs. TL and RF vs. TW (without ovary).

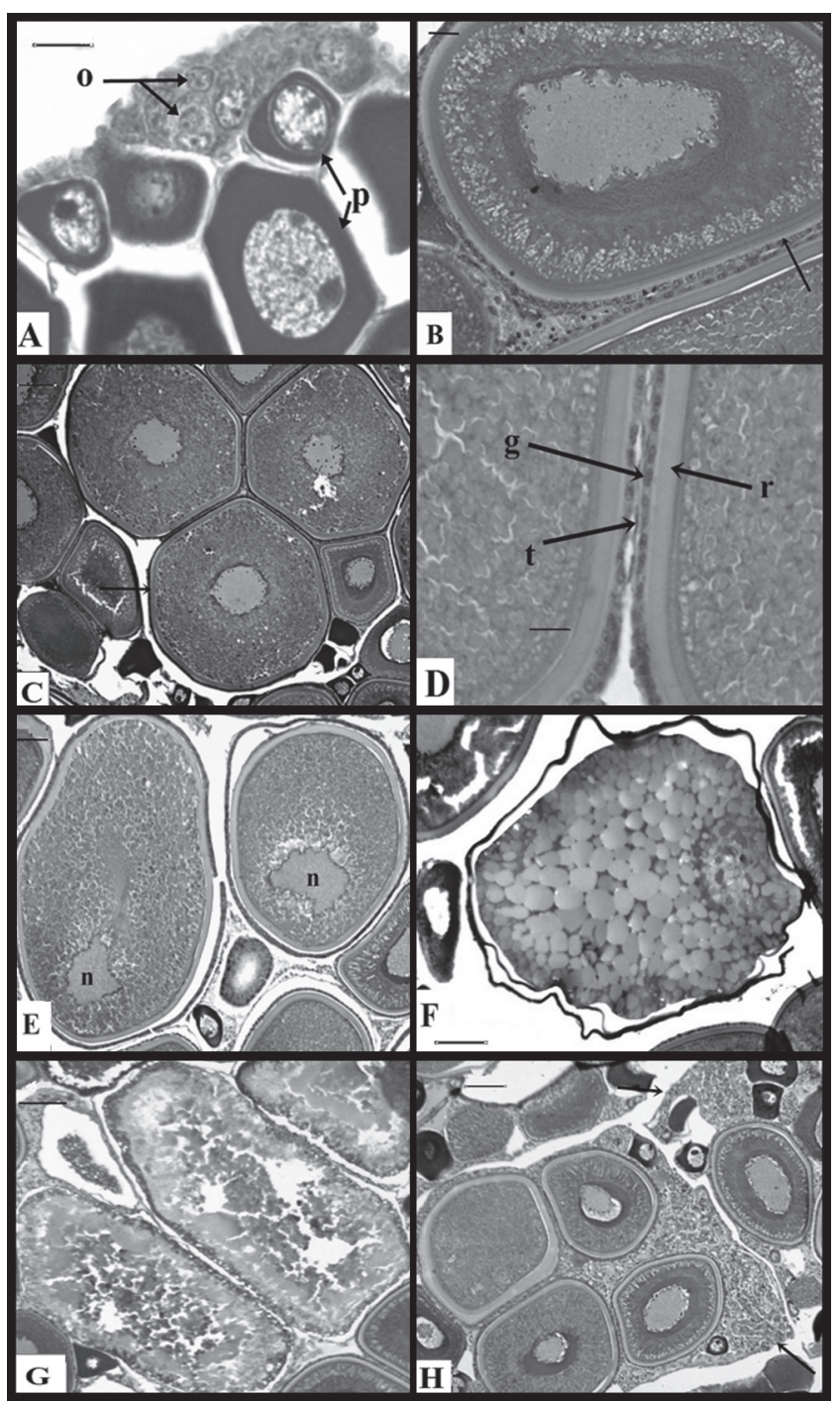

Fig. 4. Stages of oocyte development of Anchoa marinii. A, oogonias (o) and primary growth (p) oocytes; B, cortical alveoli stage oocyte (arrow); C, yolked oocytes (arrow); D, details of a yolked oocyte (r: radiata zone; g: granulosa cells; t: teca cells); E, migration of the nucleus (n); F, hydrated oocytes; G, atretic follicle; $\mathrm{H}$, post- ovulatory follicle (arrow). Scale bars: A, B, D, $20 \mu \mathrm{m}$; C, E, F, G, H, $70 \mu \mathrm{m}$.

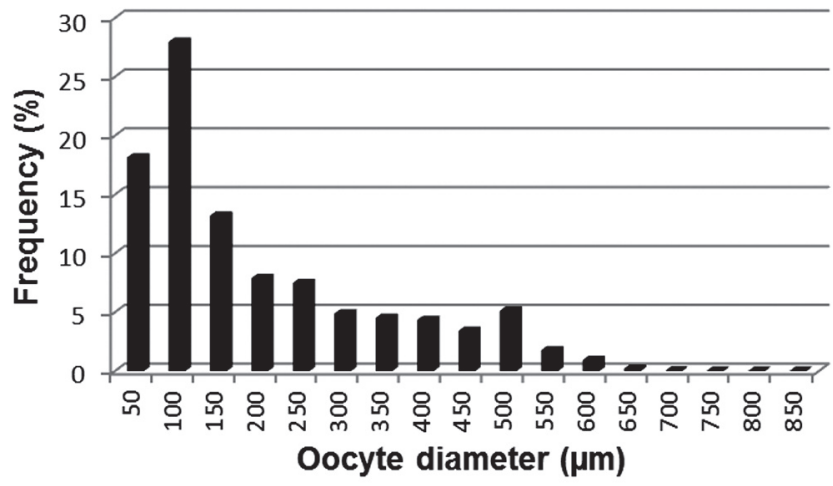

Fig. 5. Oocyte diameter distribution in spawning capable phase of Anchoa marinii. N=183. 

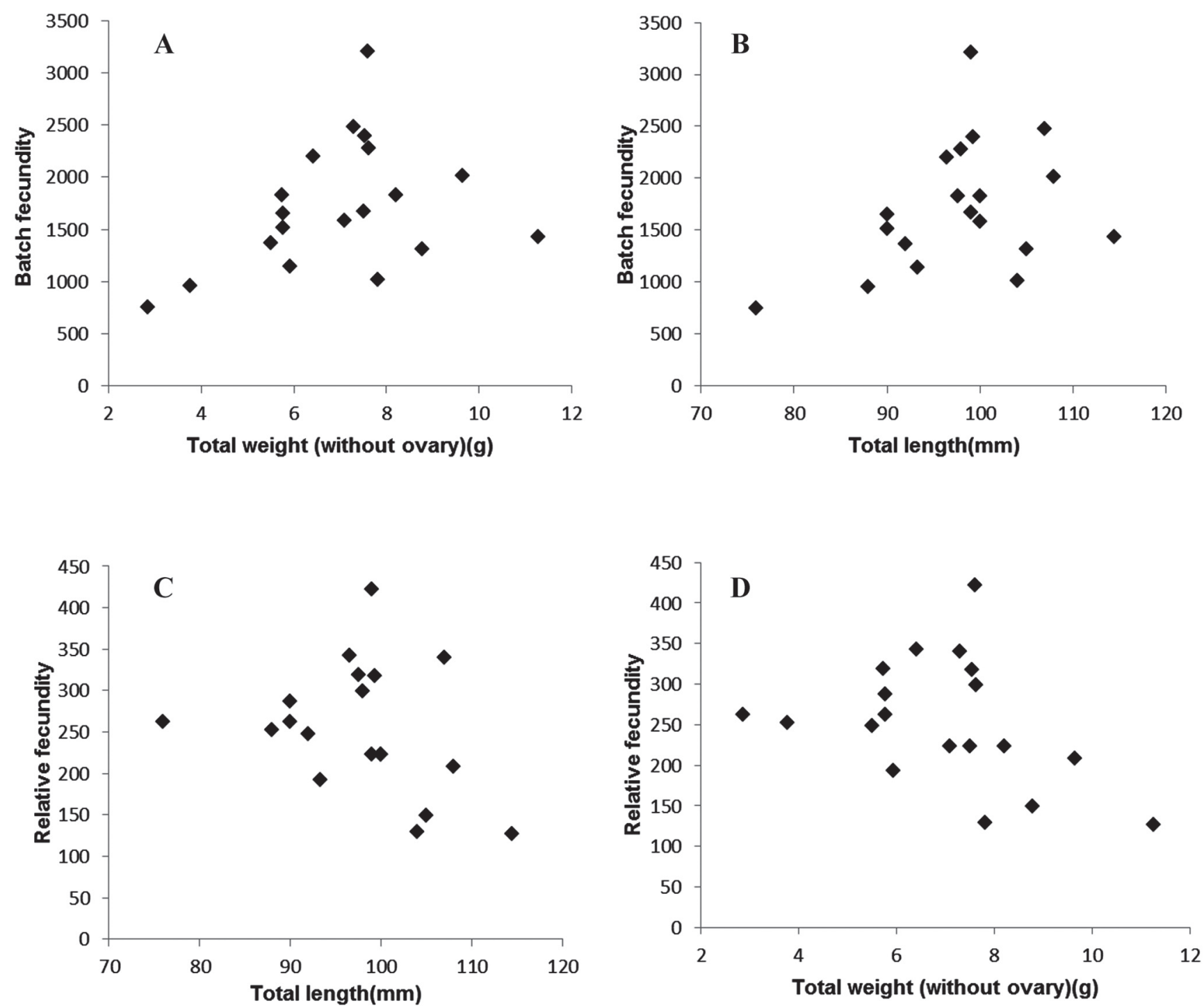

Fig. 6. A and C: Batch fecundity as a function of total length and total weight (without ovary), respectively. B and D: relative fecundity as a function of total length and total weight (without ovary), respectively.

Gonadosomatic index (GSI). Median values of GSI estimated for each maturity phase in females showed significant differences as revealed by ANOVA $(\mathrm{P}=0.00)$. The median gonadosomatic index increased from October to February (Fig. 7). Spawning activity was observed during this period. The specimens displaying the lower GSI values in January were in developing phase.

Length at first maturity $\left(\mathbf{L}_{50}\right)$. The $\mathrm{L}_{50}$ values were of $74.13 \mathrm{~mm}$ and $73.76 \mathrm{~mm} \mathrm{TL}$, obtained for females and males respectively. This result suggests that males of $A$. marinii mature at a smaller size than females, but the values were very close. $100 \%$ maturity was attained at 84 $\mathrm{mm} \mathrm{TL}$ in females and at $80 \mathrm{~mm}$ TL in males. Figure 8 shows the percentages of maturity observed in males and females for each size class, as well as adjustment sigmoid logistic parametric model employed.

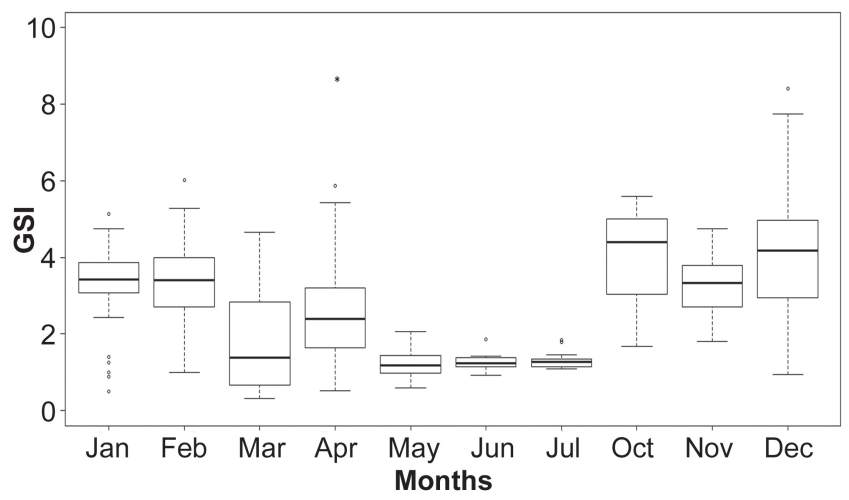

Fig. 7. Monthly variation of the gonadosomatic index (GSI), based on an annual cycle. Boxplots with median, 75th percentile and 25th percentile. Bars denote standard deviation. Open circles $=$ outlier values; asterisk $=$ extreme outliers. 

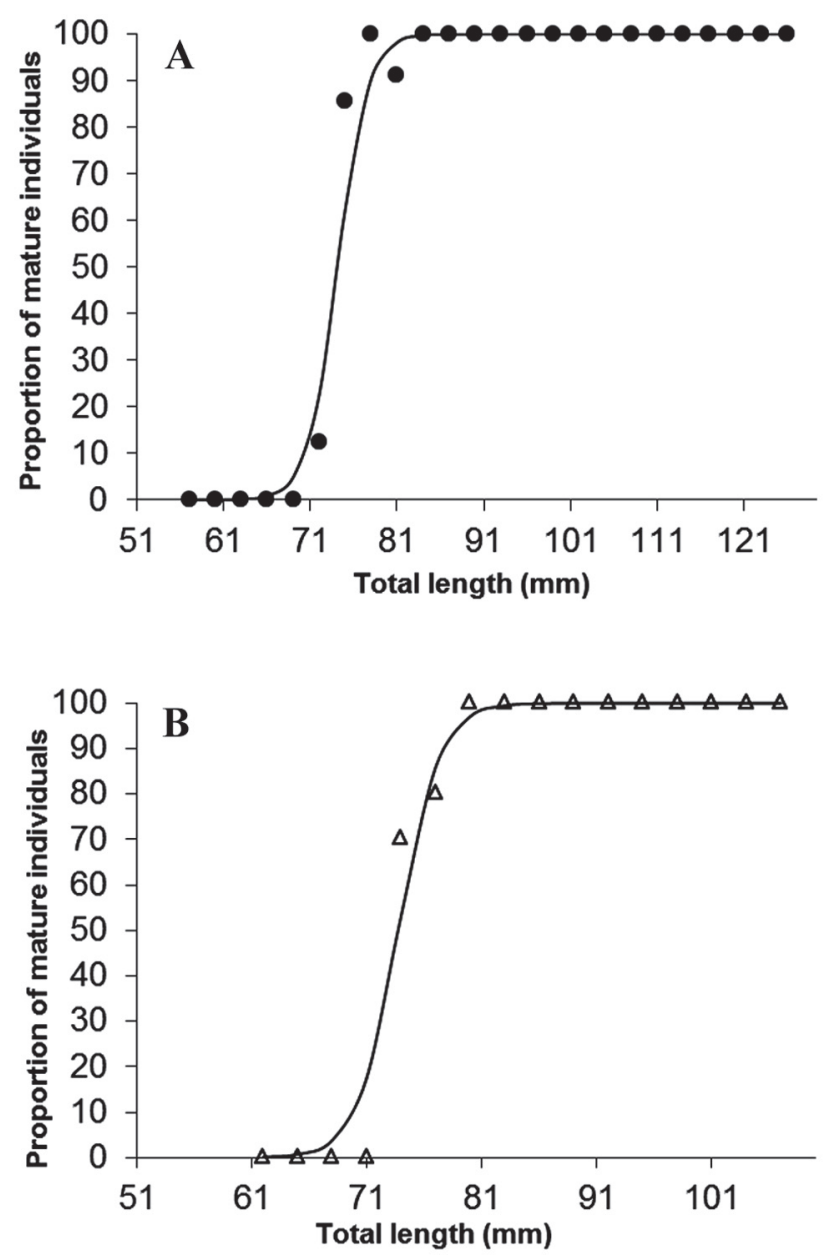

Fig. 8. Proportion of mature individuals observed for each length classes of Anchoa marinii. A. Females, B. Males.

\section{Discussion}

We provide the first contribution about the reproductive biology of the $A$. marinii in Argentina, with a histological overview. Fuster de Plaza \& Boschi (1959) provided some information concerning sexual cycle of the species, employing specimens of Mar del Plata coast. However, these authors could not perform a regular sampling based on monthly data, in order to infer the life cycle of anchovy. They neither estimated any of the biological parameters usually employed in the reproductive biology of fishes.

The oocyte diameter distribution, but also the histological analysis, showed different batches of growing oocytes, which ranged from the primary growth to vitellogenesis stages. With respect to the final maturation phase, we observed some specimens displaying oocytes with germinal vesicle migrating to the animal pole of the oocyte. Unfortunately, in only one specimen was observed oocytes with partial hydration. These observations and the findings of postovulatory follicles in ovaries with yolked oocytes, indicates that $A$. marinii is a multiple spawner with indeterminate annual fecundity sensu Hunter et al. (1992). This species displayed continuous oocytes recruitment throughout the reproductive season (January, April). Batch spawner has been suggested for other Clupeiform species, i.e. Engraulis anchoita (Brodsky \& Cousseau, 1979), Ramnogaster arcuata (Rodrigues et al., 2008) and Brevoortia aurea (Macchi \& Acha, 2000). The oocyte diameter distribution of A. marinii showed four clutches/ groups of oocytes easily differentiable in histological slides (between 50 and $650 \mu \mathrm{m}$ ) and ovaries displayed a continuous distribution from primary growth to advanced yolked oocytes. In $R$. arcuata, Rodrigues et al. (2008) found five groups of oocytes. The first four groups, as in A. marinii, showed a continuous distribution and were composed of primary growth oocytes, cortical alveolus stage, early yolked oocytes and advanced yolked oocytes. In $R$. arcuata the size was slightly larger, up $725 \mu \mathrm{m}$. In B. aurea, Macchi $\&$ Acha (2000), found four groups of oocytes, where the first three groups were nearly similar to those of $A$. marinii. The last group for $B$. aurea and $R$. arcuata corresponded to hydrated oocytes, which were not found for $A$. marinii in the present work. It was remarkable the presence of females in advanced maturity phase between December and April. During this period, a significant increase in the abundance of the species was correlated with high values of water temperature (above $16^{\circ} \mathrm{C}$ ) (Fig. 3). This fact, together with the detection of post ovulatory follicles, indicates the existence of reproductive events in the study area.

It is noticeable the sudden drop in capture per unit effort (CPUE) from May to July, but also the absence of specimens in August and September. No previously documented data exists, and one plausible hypothesis is that, during this period the anchovy could move northward in order to reach warmer waters. Another hypothesis may be the displacement of this species away from the coast with feeding purposes. Similarly, a feeding migration has been documented for $E$. anchoita (Angelescu \& Cousseau, 1967). During the winter and part of spring, individuals of Buenos Aires population of E. anchoita are found in southern Brazilian waters, arriving early shoals to the Argentine coastal waters in September (Angelescu \& Cousseau, 1967). The massive occurrence of E. anchoita during the peak of the breeding season resulted when the water temperature reaches $16^{\circ} \mathrm{C}$ (Hansen, 2000). It has also been recorded that anchovy shoals have been reported away from the coast, once the breeding season ended, to feed intensively (Hansen, 2000).

The highest GSI values were obtained between October and February. During these months most specimens were in the spawning capable phase. The low values presents on January were due to developing organisms. Moreover, the dispersion in GSI values on summer, may be due to the presence of partially spent specimens. In another clupeiform, Engraulis ringens, the highest values of GSI was consistent with the time of greatest reproductive activity, as in the case of $A$. marinii, but value was higher (>4) (Cubillos et al., 
1999; Mori et al., 2011). In Sardinella aurita, Mustac and Sinovčić (2012) found that maximum monthly average was 3.4 when intensive spawning took place.

For most teleost fishes, males become sexually mature earlier than females (Jones, 1974), but in the present study the $\mathrm{L}_{50}$ values estimated were almost equal: 74.13 and 73.76 $\mathrm{mm} \mathrm{TL}$, for females and males respectively. This is the first estimation of $\mathrm{L}_{50}$ for the species and represents $51 \%$ of maximum length. In E. ringens of south central Chile, the $\mathrm{L}_{50}$ was $11.5 \mathrm{~cm}$ for females, represent $60 \%$ of maximum length (Cubillos et al., 1999). Similarly, the $\mathrm{L}_{50}$ estimated for Buenos Aires population of E. anchoita was $97.3 \mathrm{~mm}, 49 \%$ of maximum length (Hansen, 2004). When a relationship between maximum length and $\mathrm{L}_{50}$ was established for these species, the highest percentage corresponded to E. ringens, but for A. marinii and E. anchoita was similar.

In the present paper, complete vitellogenic oocytes (the more advanced clutch of oocytes, with a diameter $\geq 500 \mu \mathrm{m}$, confirmed by microscopic observation) were employed for the fecundity estimation. According to Hunter \& Goldberg (1980), it can be employed the most advanced modal group for estimation the batch fecundity, with similar results to those based on counts of hydrated oocytes. However, this last method does not consider the influence of the incidence of atresias in the overestimation of fecundity. The batch fecundity estimates of $A$. marinii ranged between 749 and 3207 oocytes/ female. As far as we know, this represents the first contribution to fecundity estimates for the species. These values were higher when compared with those obtained for $R$. arcuata (570-2,026; 75-116 mm TL) (Rodrigues et al., 2008), but lower than the Buenos Aires stock of E. anchoita (Pájaro et al., 1997) $(13,675+/-856 ; 100-189 \mathrm{~mm} \mathrm{TL})$. The relative fecundity values ranged from 127 to 422 yolked oocytes per female gram (ovary free). Similar results were estimated for $R$. arcuata (150-437 oocytes/female gram) (Rodrigues et al., 2008), but lower for E. anchoita (574 +/21) (Pájaro et al., 1997). Noteworthy, absence of correlation between both, fecundity- TL but also fecundity- TW was detected when employed the Test of Pearson correlation. However, a relatively low number of samples was employed $(\mathrm{N}=20)$.

In conclusion, this is the first step in the reproductive biology of the Atlantic southward stock of A. marinii. Therefore, future research should be focused to obtain specimens with hydrated ovaries, in order to accurately define the spawning sites but also to corroborate the fecundity estimates. Moreover, it will be necessary to expand the sampling area, to infer the plausible movements of this species and hypothesize a life-history model.

\section{Acknowledgments}

The authors would like to thank: Juliana Giménez (CONICET) and Alejandro Sicardi, for technical assistance in the histological procedures; Ariel Martinez, for logistical support; Mar Chiquita coastal lagoon authorities; Matias
Delpiani, Daniel Bruno, Damian Castellini, Carlos Jurado and Nicolas Lajud for helping in collecting specimens; Paula Orlando and Lourdes Corbo by assistance in sampling. This work was supported by CONICET PIP 0942 and 15/ E525, EXA 577/2 UNMdP grants, but also personal funds of MGC.

\section{References}

Angelescu, V. \& M. B. Cousseau. 1967. Distribución espacial y cronológica de la anchoíta en el Mar Epicontinental Argentino; relaciones con el desarrollo de las pesquerías pelágicas. CARPAS (FAO) /3/Documento Técnico, Montevideo, Uruguay, 1: 1-48.

Bakun, A. \& K. Broad. 2003. Environmental "loopholes" and fish-population dynamics: comparative pattern recognition with focus on El Niño effects in the Pacific. Fisheries Oceanography, 12: 458-473.

Brodsky, S. \& M. B. Cousseau. 1979. El ciclo reproductivo de la anchoita de la plataforma bonaerense. Pisces, Fam. Engraulidae, Engraulis anchoita. Acta Lilloana XXXV. Instituto Nacional de Investigación y Desarrollo Pesquero. Contribución n. 349.

Brown-Peterson, N. J., D. M. Wyanski, F. Saborido-Rey, B. J. Macewicz \& S. K. Lowerre-Barbieri. 2011. A Standardized terminology for describing reproductive development in fishes. Marine and Coastal Fisheries: Dynamics, Management, and Ecosystem Science, 3: 52- 70.

Ciechomski, J. D. de. 1968. Huevos y larvas de tres especies de peces marinos, Anchoa marinii, Brevoortia aurea y Prionotus nudigula de la zona de Mar del Plata. Boletín Instituto Biología Marina, 17: 1-27.

Cousseau, M. B., J. M. Díaz de Astarloa \& D. E. Figueroa. 2001. La Ictiofauna de la laguna Mar Chiquita. Pp. 187-203. In: Iribarne, O. (Ed.). Reserva de Biósfera Mar Chiquita: características físicas, biológicas y ecológicas. Mar del Plata, Editorial Martín.

Cousseau, M. B. \& R. G. Perrota. 2004. Peces marinos de Argentina: biología, distribución y pesca. Mar del Plata, INIDEP.

Cubillos, L. S., M. A. Canales., D. S. Bucarey, A. S. Rojas \& R. M. Alarcón. 1999. Época reproductiva y talla media de primera madurez sexual de Strangomera bentincki y Engraulis ringens en el período 1993-1997, en la zona centro- sur de Chile. Investigaciones Marinas, Valparaíso, 27: 73-85.

Cury, P., L. Shannon\& Y. J. Shin. 2003. The functioning of marine ecosystems: a fisheries perspective. Pp. 103, 123. In: Sinclair, M. \& G. Valdimarsson (Eds.). Responsible fisheries in the marine ecosystem. Rome, FAO and CABI Publishing.

Díaz de Astarloa, J. M., D. E. Figueroa, M. B. Cousseau \& M. Barragán. 2000. Occurrence of Trachinotus carolinus (Carangidae) in Laguna Costera Mar Chiquita, with comments on other occasionally recorded fishes in Argentinean waters. Bulletin of Marine Science, 66: 399-404.

Fréon, P. \& O. A. Misund. 1999. Dynamics of pelagic fish distribution and behaviour: effects on fisheries and stock assessment. Oxford, Fishing News Books. 348p.

Fuster de Plaza, M. L \& E. E. Boschi. 1959. Nuevos datos sobre la biología de la especie Anchoa marinii, Hildebrand de Mar del Plata. Actas y trabajos del primer congreso Sudamericano de Zoología. La Plata, 12- 24 octubre 1959. Tomo IV. 
González Castro, M., J. M. Díaz de Astarloa \& M. B. Cousseau. 2006. First record of a tropical affinity mullet, Mugil curema (Actinopterygii: Mugilidae), in a temperate Southwestern Atlantic coastal lagoon. Cybium, 30: 90-91.

González Castro, M., J. M. Díaz de Astarloa., M. B. Cousseau., D. E. Figueroa., S. M. Delpiani., D. Bruno., J. M. Guzonni., G. E. Blasina \& M. Y. Deli Antoni. 2009. Fish composition in a south-western Atlantic temperate coastal lagoon: spatialtemporal variation and relationships with environmental variables. Journal of the Marine Biological Association of the United Kingdom, 89: 593- 604.

González Castro, M., G. J. Macchi \& M. B. Cousseau. 2011. Studies on reproduction of the mullet Mugil platanus Günther, 1880 (Actinopterygii, Mugilidae) from the Mar Chiquita coastal lagoon, Argentina: similarities and differences with related species. Italian Journal of Zoology, 78: 343-353.

Hansen, J. E. 2000. Anchoita (Engraulis anchoita). Pesquerias de Argentina, 1997-1999: 205-216.

Hansen, J.E. 2004. Anchoíta (Engraulis anchoita). Pp. 101-115. In: Sánchez, R. P. \& S. I. Bezzi (Eds). El Mar Argentino y sus recursos pesqueros. Tomo 4. Los peces marinos de interés pesquero. Caracterización biológica y evaluación del estado de explotación. Mar del Plata, Publicaciones Especiales INIDEP.

Hildebrand, S. F. 1943. A review of the American anchovies (family Engraulidae). Bulletin of the Bingham Oceanographic Collection Yale University 8: 1-165.

Hunter, J. R \& S. R. Goldberg. 1980. Spawning incidence and batch fecundity in northern anchovy, Engraulis mordax. Fishery Bulletin, 77: 641- 652.

Hunter, J. R., B. J. Macewicz, N. C. H. Lo \& C. A. Kimbell. 1992. Fecundity, spawning and maturity of female Dover sole Microstomus pacificus, with an evaluation of assumptions and precision. Fishery Bulletin, 90: 101-128.

Iribarne, O. 2001. Reserva de Biosfera Mar Chiquita: características físicas, biológicas y ecológicas. Mar del Plata, Argentina: Editorial Martín. 320p.

Jones, A. 1974. Sexual maturity, fecundity, and growth of the turbot, Scophthalmus maximus. Journal of the Marine Biological Association of the United Kingdom, UK, 54: 109-125.

Kartas, F \& J. P. Quignard. 1984. La Fecondite des poissons teleosteens. Paris, Masson. 121p.
López, S. 2013. Abundancia, distribución y biología reproductiva de la anchoa, Anchoa marinii Hildebrand, 1943 que habita en la franja submareal frente a la laguna costera Mar Chiquita. Unpublished Ms. C. Thesis, Universidad Nacional de Mar del Plata, Mar del Plata, 62p.

Mantero, G., S. Retta \& R. Rodríguez. 2006. Ictioplancton costero de la zona de transición estuarina del Río de la Plata (Uruguay). Pp. 437-445. In: Menafra, R., L. Rodriguez-Gallago, F. Scarabino \& D. Conde (Eds.). Bases para la conservación y el manejo de la costa uruguaya. Montevideo, Vida Silvestre Uruguay, $668 \mathrm{p}$.

Macchi, G. J. \& E. M. Acha. 2000. Spawning frequency and batch fecundity of Brazilian menhaden, Brevoortia aurea, in the Río de la Plata estuary off Argentina and Uruguay. Fishery Bulletin, 98: 283-289.

Mori, J., B. Buitrón, A. Perea, C. Peña \& C. Espinoza. 2011. Interannual variability of the reproductive strategy of the Peruvian anchovy off northern- central Peru. Ciencias Marinas. International Journal of Marine Sciences, 37: 513525.

Mustac, B. \& G. Sinovčić. 2012. Reproductive cycle of gilt sardine, Sardinella aurita, Valenciennes 1847, in the eastern middle Adriatic Sea. Journal of Applied Ichthyology, 28: 46- 50.

Pájaro, M., G. J. Macchi \& R. P. Sánchez. 1997. Fecundidad y frecuencia reproductiva de las poblaciones bonaerense $\mathrm{y}$ patagónica de la anchoíta argentina (Engraulis anchoita). Revista de Investigación y Desarrollo Pesquero, 11: 19-38.

Rivera Prisco, A., S. B. García de La Rosa \& J. M. Díaz de Astarloa. 2001. Feeding ecology of flatfish juveniles (Pleuronectiformes) in Mar Chiquita coastal lagoon (Buenos Aires, Argentina). Estuaries, 24: 917-925.

Roa, R., B. Ernst \& F. Tapia. 1999. Estimation of size at sexual maturity: an evaluation of analytical and resampling procedures. Fishery Bulletin, 97: 570-580.

Rodrigues, A. K., G. J. Macchi, E. M. Acha \& M. I. Militelli. 2008. Spawning and fecundity of Jenyns's sprat, Ramnogaster arcuata, a winter spawner in the temperate waters of the Río de la Plata estuary, Argentina-Uruguay. Journal of the Marine Biological Association of the United Kingdom, 88: 423-429.

Submitted Jun 5, 2014 Accepted October 27, 2014 by Clarice Fialho Published March 31, 2015 